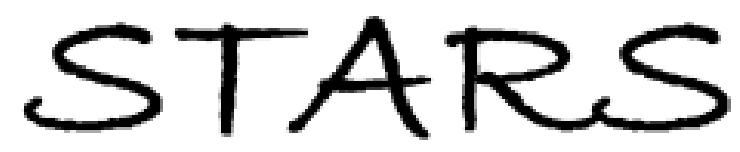

University of Central Florida

STARS

$1-1-1984$

\title{
An Exploratory Examination Of The Effect Of Remarriage On Child- Support And Personal Contacts
}

Walter D. Tropf

University of Central Florida

Find similar works at: https://stars.library.ucf.edu/facultybib1980 University of Central Florida Libraries http://library.ucf.edu

This Article is brought to you for free and open access by the Faculty Bibliography at STARS. It has been accepted for inclusion in Faculty Bibliography 1980 s by an authorized administrator of STARS. For more information, please contact STARS@ucf.edu.

\section{Recommended Citation}

Tropf, Walter D., "An Exploratory Examination Of The Effect Of Remarriage On Child-Support And Personal Contacts" (1984). Faculty Bibliography 1980s. 357.

https://stars.library.ucf.edu/facultybib1980/357

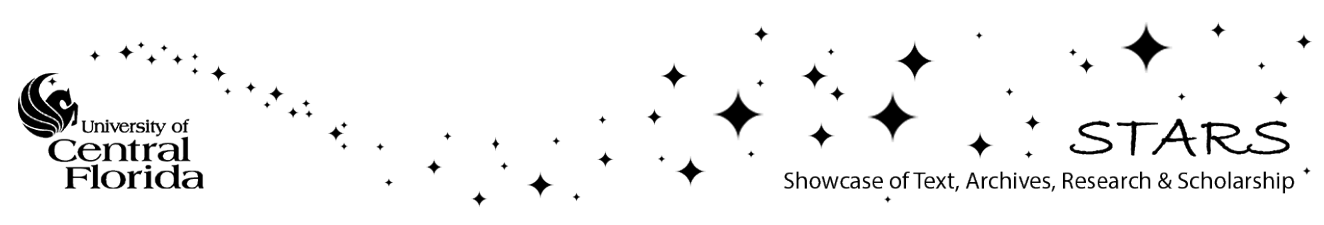




\title{
An Exploratory Examination of the Effect of Remarriage on Child Support and Personal Contacts
}

\author{
Walter D. Tropf PhD
}

To cite this article: Walter D. Tropf PhD (1984) An Exploratory Examination of the Effect of Remarriage on Child Support and Personal Contacts, Journal of Divorce, 7:2, 57-73, DOI: 10.1300/ J279v07n02_04

To link to this article: https://doi.org/10.1300/J279v07n02_04

Published online: 25 Oct 2008.

Submit your article to this journal $\widetilde{ }$

Џ Article views: 11

Q View related articles $\sqsubset$

Citing articles: 3 View citing articles 5 


\title{
An Exploratory Examination of the Effect of Remarriage on Child Support and Personal Contacts
}

\author{
Walter D. Tropf
}

\begin{abstract}
This paper examines the re-ordering of role relationships occurring after remarriage, and their effect on child support and personal contacts. Comparisons are made for three marital statuses-separation, divorce and the remarriage of either exspouse. Data were collected from a convenience sample of 101 divorced men. The findings suggest that voluntary support increases after the remarriage of the father but decreases with the remarriage of the exwife. Visiting frequency decreases, while visiting length increases with the remarriage of either exspouse. Phone calls remain relatively constant. An examination of ten intervening variables suggests that geographic distance, religion, social class, the attitude of the exwife toward the continuing father-child relationship and continuity of support payments act to reduce visiting frequency but have no effect on voluntary support. The data analysis indicates that the complexity of role configurations created by remarriage produces effects that have not received sufficient attention among researchers. Suggestions are made for further research.
\end{abstract}

There is limited empirical evidence available to indicate the extent to which fathers remain actively involved in the lives of their children following marital separation. The purpose of this study is to explore some of the factors which might impinge on a father's decision to support his children and maintain personal contacts with them. Such information can be useful in developing hypotheses for more extensive studies in the future.

As a working hypothesis, it will be assumed that child support and

Walter D. Tropf, PhD, is an assistant professor of social work at the University of Central Florida, Department of Social Work, P.O. Box 25000, Orlando, Florida 32816. An earlier version of this paper was presented at the combined annual conferences of the Southeastern Council on Family Relations and the Virginia Council on Family Relations in Blacksburg, VA, March 29-31, 1981. 
personal contacts, as dependent variables, will be affected in some way by the marital status of both the father and his exwife. Theoretically, separation removes some of the marital role obligations from both parties and divorce removes them entirely, unless alimony is involved. The remarriage of either expouse adds new marital roles and the possibility of step-parent roles. These require a re-ordering of role relationships on the part of both adults and children (Bohannan, 1971). The demands imposed by remarriage may strain the financial and personal resources of the father and require the establishment of new priorities. The situation may be aggravated if the new marriage includes step-children. The addition of a stepfather into the equation when the exwife remarries increases the possibility for conflict. The father may feel less of an obligation to support his children, or may find visiting awkward or less rewarding than when his exwife was single. The exwife may respond by applying pressure on the father to reduce, or even abandon, his parental obligations.

On the other hand, divorce does not sever the father-child bond or eliminate its obligations. New wives may be very supportive of the father maintaining a good relationship with his children. Many exwives and stepfathers want support to continue and may be willing to encourage personal contacts as a means toward that end, if for no other reason. Thus it cannot be safely assumed that role adjustments occasioned by the remarriage of either exspouse will necessarily result in reductions in the paternal role.

By using marital status as an independent variable, comparisons can be made with the father's role performance when role demands are reduced (separation and divorce) with his performance when role demands increase due to the remarriage of either exspouse.

This research will examine the effect of marital status on voluntary contributions for child support, telephone contacts and personal visits. Additional intervening variables will be introduced as suggested by the studies discussed in the literature review.

\section{LITERATURE REVIEW}

Goode's (1965) well-known study of divorce, in which he examined the post-divorce behavior of 425 women, indicated that only $35 \%$ of his sample reported receiving regular support payments and $40 \%$ reported support payments as rare or never. The failure of divorced men to support their children has become a part of 
American folklore and is supported by census data indicated below.

Information on the amount of personal contacts that occur between father and child after divorce, and how these might change over time, has received little attention. Goode suggests that paternal visiting will decrease in frequency as the father finds visits less pleasurable than expected and as both he and his exwife find new interests and new role obligations. Respondents in his study were asked to comment on the desired frequency of paternal visits. Expressed desires for less frequent visits were related to time elapsed since the divorce, steadiness of payments, her remarriage, children's responses to visiting and the exwife's desire to punish her exhusband. The three most important variables were her remarriage, continuity of support and the children's behavior following visits.

Based on clinical interviews and case studies with largely white, middle class respondents, Weiss (1975) confirms a reduction in visiting frequency over time. He suggests that there are three important variables affecting visiting frequency. These are ages of the children, geographic distance and social class. Visiting is likely to be less frequent when children are preschoolers or adolescents. At these ages frequent visits may not be desirable. In addition, problems in arranging for child care with very young children may pose practical problems.

Moves to another geographic region will, of course, reduce visiting frequency; however, Weiss suggests that middle and upper income fathers will be able to visit more frequently than those with lower incomes.

Hetherington, Cox, and Cox (1976) have presented some of their preliminary findings of a longitudinal study of the impact of divorce on the functioning of 96 families. Part of their goal was to study the reorganization of the family in the two-year period following divorce. A comparison was made of divorced and intact families matched for social class, age, education and length of marriage of the parents; and age, sex and birth order of the children. All respondents were white and middle class. Investigative measures included laboratory observations, interviews and structured diaries applied at two months, one year and two years after divorce.

Contacts between divorced father and child decreased steadily over time. At two months, divorced fathers were having about as much face-to-face interaction as were fathers in intact homes. One quarter of the divorced fathers were having more face-to-face interaction than they had had before the divorce. By the end of the twoyear period, 19 fathers were seeing their children one or more times 
a week, 14 every two weeks, seven every three weeks and eight once a month or less. Eight fathers coped with the stress of separation from their children by reducing contacts.

Several other exploratory studies have yielded information pertinent to an understanding of post-divorce relationships between father and child. Anspach (1976) studied kinship relations after divorce and, while his study did not deal directly with father-child relationships, slightly over half of the exwives studied reported that the fathers of their children did not visit.

Newsome (1977) tested the hypothesis that the father's access to his children would be controlled by the exwife and the greater his contribution to his first family, the greater the access. Generally he found the hypothesis supported.

Alexander (1980) investigated the ways in which divorced parents determined visiting arrangements. She found only one respondent reporting that visiting declined after remarriage; however, the number of exspouses in the sample who had remarried was small and it is not clear whether it was the custodial or the noncustodial parent who had remarried. She also found that hostility between the exspouses was not a significant factor in meeting the best interests of the child when making visiting arrangements.

Other studies affirm the great likelihood of conflicting relations between exspouses although they do not necessarily relate the conflict to continuing child support or personal contacts (Weiss, 1975; Hetherington et al., 1976; Goldsmith, 1979; Cline and Westerman, 1971).

Another variable which could be assumed to affect both support and contacts is the amount of satisfaction or dissatisfaction experienced by the father with his post-divorce paternal role. Fathers who find parenting from a distance insufficiently rewarding or too stressful, might be expected to reduce their involvement to a minimum. While no research was found to support this assumption, several authors have affirmed the heavy negative impact of divorce on paternal role satisfaction (Weiss, 1975; Hetherington et al., 1976; Goldsmith, 1979; Newsome, 1979; Grief, 1977).

\section{SAMPLE AND METHOD}

A convenience sample was used numbering 101 men. The population from which the sample was drawn consisted of men living in 
the greater Orlando (Florida) area, remarried or not, who had had children by a previous marriage.

Personal interviews were conducted using a structured questionnaire with some open-ended questions. Only a small portion of the data collected is reported in this paper. Additional findings included information on custody, paternal role satisfaction, relationship with the exwife and the current wife and attitudes toward stepparenting. Observations from these data will be made in the discussion when they shed light on the findings or support internal validity.

For purposes of this study, personal contacts between father and child were defined as phone calls and visits regardless of whether they were originated by the father or the child. Phone calls and visits were measured for frequency on an eight-point scale from daily to less than yearly. In the findings these are dichotomized as "frequent" (more than once per month) or "infrequent" (once per month or less). Visits were also measured for duration on a fivepoint scale from two hours or less to a week or more. These are dichotomized as "long" (overnight or more) to "short" (one day or less).

Financial support was measured by whether or not the father sent extra funds (beyond the required support) at the request of either the child or the exwife. Respondents were asked to indicate if they always responded to such requests, sometimes refused, sometimes could not respond or never responded. Voluntary contributions were used rather than court ordered payments in order to provide a measure of support free of coercion.

Role obligations were measured by the marital status of the divorced couple. Three marital statuses were defined-separation, divorce and remarriage, with the latter specified as the remarriage of the father or the remarriage of the exwife.

Hypotheses were tested by using the Chi-square test of independence. Either the Phi coefficient or Cramer's V was used to test for significance. Alpha was set at .05.

Based on the literature and on information gained from pretest interviews, ten factors were operationalized as intervening variables which might act to influence the relationship between the dependent and independent variables. These were geographic distance, religion, social class, continuity of support payments, whether or not the exwife supported or opposed visiting, the relationship between the exspouses, the emotional difficulty the father experienced in visiting and the attitudes of the present wife. This latter variable 
included her attitudes toward the exwife, toward the time devoted to the children and toward the money spent on the children. Only the first five intervening variables appeared to affect the dependent variables and these only affected personal contacts. Following is an explanation of the measures of these five variables.

Geographic distance between father and child was dichotomized as "less than 150 miles" or " 151 miles or more." Religion was defined as simply Protestant, Catholic, Jewish and Other with no attempt to measure religiosity. Social class was measured by Hollingshead's Two Factor Index (Hollingshead and Redlich, 1958).

Support payments were classified as stopped if respondents were more than two weeks late or missed payments for a period of time up to three months; or if respondents had ever stopped payments for three months or more.

The exwife's opposition to, or support of, the father's visits with his children was measured at the time of the divorce and at the time of the interview. Unfortunately, it was not measured at the other two marital statuses (separation and remarriage). The possible responses to the question were "strongly oppose", "some oppose", "neutral", "some support" or "strongly support".

Both the age of the children and their behavior following visits were described in the literature as having potential signifiance. Unfortunately the method of computer analysis used did not allow for controlling by children's age. Since the divorced fathers were interviewed rather than the exwives, direct evidence regarding the children's behavior following visits was not available.

\section{DESCRIPTION OF THE SAMPLE}

The men in the sample averaged 37.4 years of age and all but five were Caucasian. Sixty were Protestant, 24 Catholic and the remainder were of some other religion, non-affiliated or did not respond. The majority of respondents fell into Classes I and II on the Hollingshead scale which has been characterized by Kessler and Cleary as the middle classes (1980). There was no statistically significant relationship between religion and social class and Protestants predominated at all class levels. Forty-one men had some college education, 21 were college graduates and 14 had graduate degrees. The sample consisted predominately of white, Protestant, middle class and professional respondents. 
Seventy-six of the men had remarried and $86.8 \%$ (66) of these second marriages were still intact. Twenty-five had not remarried.

Of the exwives of the first marriage, 49 had remarried and 50 had not. Only two men did not know anything about the marital status of their first wives.

\section{FINDINGS}

The findings concerning the effect of remarriage on voluntary child support revealed some unexpected behavior. By looking at Table 1, it can be seen that a request from the child receives an increased favorable response after the divorce when compared to the separation period (from $13.6 \%$ to $22.7 \%$ ). When the request comes from the exwife, the favorable response drops slightly from $35.6 \%$ to $32.5 \%$ for the same change in status.

With the remarriage of the father the favorable responses rise to $27.9 \%$ at the child's request and to $48.3 \%$ at the request of the exwife.

TABLE 1

RESPONSE OF DIVORCED FATHER TO CHILD'S AND EX-WIFE'S REQUEST FOR EXTRA MONEY BY MARITAL STATUS

Marital Status

\begin{tabular}{|c|c|c|c|c|c|c|c|c|}
\hline \multirow[b]{2}{*}{$\begin{array}{l}\text { Response to Request } \\
\text { From Child }\end{array}$} & \multicolumn{2}{|c|}{ Separated } & \multicolumn{2}{|c|}{ Divorced } & \multicolumn{2}{|c|}{$\begin{array}{l}\text { Father } \\
\text { Remarried }\end{array}$} & \multicolumn{2}{|c|}{$\begin{array}{l}\text { Ex-wife } \\
\text { Remarried }\end{array}$} \\
\hline & \& & $N^{*}$ & $\%$ & $\mathrm{~N}$ & $\%$ & N & $\%$ & $\mathrm{~N}$ \\
\hline Favorable & 13.6 & (8) & 22.7 & (15) & 27.9 & (12) & 20.0 & (5) \\
\hline Unfavorable & 86.4 & (51) & 77.3 & (51) & 72.1 & (31) & 80.0 & (20) \\
\hline TOTALS & 100.0 & (59) & 100.0 & $(66)$ & 100.0 & (43) & 100.0 & (25) \\
\hline
\end{tabular}

Response to Request From Ex-wife

\begin{tabular}{lrrrrrrrr}
\hline $\begin{array}{l}\text { Favorable } \\
\text { Unfavorable }\end{array}$ & 35.6 & $(26)$ & 32.5 & $(25)$ & 48.3 & $(18)$ & 25.0 & (7) \\
\hline TOTALS & 64.4 & $(47)$ & 67.5 & $(52)$ & 61.7 & $(29)$ & 75.0 & $(21)$ \\
\hline
\end{tabular}

*Number of Fathers 
After the remarriage of the exwife the favorable responses drop sharply to $20.0 \%$ at the child's request and $25.0 \%$ at the exwife's request.

It would appear, therefore, that the remarriage of the father produces a much different effect on voluntary support than does the remarriage of the exwife regardless of whether the request comes from the children or the exwife. Although none of these findings reached statistical significance, the evidence suggests that the restructuring of the support role is different following the father's remarriage than it is following the remarriage of the exwife.

The second analysis concerns phone calls and visits following the remarriage of either exspouse. There is a big drop in the frequency of phone calls between the separation and the divorce. At separation, $83.1 \%$ of fathers and children were making frequent phone calls but this dropped to $68.3 \%$ following the divorce. After the remarriage of the father, frequency decreased to $57.8 \%$ but after the remarriage of the wife frequency increased slightly over the divorce period to $69.6 \%$. These differences were significant at the .05 level although the association was weak (Cramer's $\mathrm{V}=.21$ ).

Table 2 indicates the frequency and duration of visits respectively for each of the four marital statuses. Both tables include multiple responses. That is, if the father had his children visit once a month for the weekend and also had them visit for a week or more once per year, both of these durations and frequencies are included. Longer visits are increasingly utilized as the marital statuses proceed through separation, divorce and the remarriage of either exspouse. The longer visit is utilized more however, after the remarriage of the exwife than it is after the remarriage of the father. As the visits increase in length, they decrease in frequency. Visiting more than once per month is most common during the separation period (77.0\%) but decreases to $64.9 \%$ after divorce and drops to $47.5 \%$ and $43.7 \%$ respectively with the father's remarriage and the remarriage of the exwife. Longer visits make up $44.8 \%$ of all visits during separation but increase to $58.8 \%$ after divorce and to $66.1 \%$ with the father's remarriage and $78.1 \%$ with the remarriage of the exwife.

The findings on both visiting frequency and duration were significant at the .005 level. The association was weak in both instances with Cramer's V $=.23$ for frequency and .22 for duation.

The evidence indicates that marital status has an effect on visiting frequency by reducing the frequency of visits while increasing their 
TABLE 2

FREQUENCY AND DURATION OF VISITS BY MARITAL STATUS

\begin{tabular}{|c|c|c|c|c|c|c|c|c|}
\hline \multirow[b]{3}{*}{ Frequency } & \multirow[b]{3}{*}{$\%$} & \multicolumn{7}{|c|}{ Marital Status } \\
\hline & & Separated & & Divorced & & $\begin{array}{l}\text { Father } \\
\text { Remarried }\end{array}$ & & $\begin{array}{l}\text { Ex-wife } \\
\text { Remarried }\end{array}$ \\
\hline & & $\mathrm{N}^{*}$ & 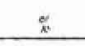 & N & $\%$ & $\mathrm{~N}$ & $\%$ & $\mathrm{~N}$ \\
\hline Frequent** & 77.0 & (67) & 64.9 & (63) & 47.5 & (28) & 43.7 & (14) \\
\hline Infrequent** & 23.0 & $(20)$ & 35.1 & (34) & 52.5 & (31) & 56.3 & (18) \\
\hline TOTALS & 100.0 & (87) & 100.0 & $(97)$ & 100.0 & (59) & 100.0 & (32) \\
\hline
\end{tabular}

Duration

\begin{tabular}{rrrrrrrrr}
\hline Long*** & 44.8 & $(39)$ & 58.8 & $(57)$ & 66.1 & $(39)$ & 78.1 & $(25)$ \\
Short*** & 55.2 & $(48)$ & 41.2 & $(40)$ & 33.9 & $(20)$ & 21.9 & $(7)$ \\
\hline \multicolumn{1}{c}{ TOTALS } & 100.0 & $(87)$ & 100.0 & $(97)$ & 100.0 & $(59)$ & 100.0 & $(32)$ \\
\hline
\end{tabular}

* Number of Fathers

**Frequent = More than one visit per month

** Infrequent $=$ One visit per month or less

$* * *$ Long $=$ One overnight visit or more

***Short $=$ One day visit or less

$\begin{array}{llc} & \frac{\text { Significance Level }}{\text { Visiting Frequency }} & \frac{\text { Cramer's V }}{.23} \\ \text { Visiting Duration } & P<.005 & \\ & X^{2}=14.31, \text { d.f. }=3 & .22 \\ & P<.005 & \\ & X^{2}=13.25, \text { d.f. }=3 & \end{array}$

length. The effect on frequency is about the same regardless of which exspouse remarries. Obviously examining frequency and duration of visits together explains a lot more than looking at only one indicator. However, except for Hetherington et al., most researchers have used frequency as a measure of visiting behavior. Since the intervening variables can only be examined along one of these dimensions at a time, frequency was selected for examining the effects of intervening variables.

In order to examine the effects of the 10 intervening variables on visiting frequency it was necessary to construct a second model of visiting frequency that eliminated visiting length so that just frequency could be entered into the computer. This required summar- 
izing visiting frequency so that just the visiting mode reflecting the greatest number of visits was used; i.e., if a father had his child visit every month for a day and quarterly for a week, only the monthly visit was counted since it represented the greatest frequency. Therefore, the total $n$ reported in the following discussion will be less than that of Table 2. The maximum reduction in $n$ for any one marital status is 21 . Since the trend of reducing visits for each change in marital statuses is maintained, any distortion will not substantially affect the validity of the findings.

The second model also yielded information about those who never visit. During separation, $14.1 \%$ reported that they never visited their children. This dropped slightly to $12.6 \%$ after divorce but rose to $22.6 \%$ and $30.5 \%$ respectively after the remarriage of the father and the exwife. Thus, the increase in those who never visited is compatible with the decrease in visiting frequency except for the slight drop in those who never visit after divorce. The greater number, who report that they never visit during separation, may be due to the use of restraining orders that are lifted following the divorce proceedings.

As indicated above, five of the intervening variables showed no effect on visiting frequency. These were the nature of the relationship between the exspouses, the degree of emotional difficulty experienced by the father when visiting and the attitude of the present wife toward the exwife and toward the amount of time and money allocated to the children.

The five other intervening variables showed directions of interest although only one attained statistical significance. This was geographic distance. The findings on distance will be presented first, followed by the data relative to the other four variables which did not attain significance.

The data in Table 3 indicates that, when controlling for distance, the trend is for visits in the frequent category to decrease and visits in the infrequent category to increase after the remarriage of either spouse. However, the change for those fathers living further away is much greater than for those living closer. For those living the greater distance, frequent visiting decreased from $85.7 \%$ during separation to $30.0 \%$ after the father's remarriage and to $18.2 \%$ after the remarriage of the exwife. A look at the figures for those fathers living closer to their children shows a similar trend, but a less drastic change, for both frequent and infrequent visits. In these cases the drop in frequent visiting is from $83.7 \%$ during separation 
TABLE 3

FREOUENCY OF VISITS FOR FOUR MARITAL STATUSES CONTROLLING FOR DISTANCE

150 Miles or Less

Marital Status

\begin{tabular}{|c|c|c|c|c|c|c|c|c|}
\hline \multirow[b]{2}{*}{ Duration } & & \multicolumn{2}{|c|}{ Separated } & \multicolumn{2}{|c|}{ Divorced } & $\begin{array}{l}\text { Father } \\
\text { Remarried }\end{array}$ & \multicolumn{2}{|c|}{$\begin{array}{l}\text { Ex-wife } \\
\text { Remarried } \\
\end{array}$} \\
\hline & & $\approx$ & $N^{*}$ & $\%$ & $\mathrm{~N}$ & $\%$ & 8 & $\mathrm{~N}$ \\
\hline Frequent & 83.7 & (36) & 85.1 & $(40)$ & 77.4 & (24) & 66.7 & (12) \\
\hline Infrequent & 16.3 & (7) & 14.9 & (7) & 22.6 & (7) & 33.3 & (6) \\
\hline TOTALS & 100.0 & (43) & 100.0 & (47) & 100.0 & (31) & 100.0 & (18) \\
\hline
\end{tabular}

151 Miles or More

\begin{tabular}{lrrrrrrrr} 
Frequent & 85.7 & $(24)$ & 62.1 & $(18)$ & 30.0 & $(6)$ & 18.2 & (2) \\
Infrequent & 14.3 & $(4)$ & 37.9 & $(11)$ & 70.0 & $(14)$ & 81.8 & (9) \\
\hline TOTALS & 100.0 & $(28)$ & 100.0 & $(29)$ & 100.0 & $(20)$ & 100.0 & (11) \\
\hline
\end{tabular}

* Number of Fathers

$\begin{array}{lcc}\text { Marital Status } & \frac{\text { Significance Level }}{\text { Separated }} & \frac{\text { Phi Coefficient }}{\text { NS }} \\ \text { Divorced } & p<.05 & .03 \\ & x^{2}=5.25, \text { d.f. }=1 & .26 \\ \text { His Remarriage } & p<.001 & .47 \\ \text { Exwife's Remarriage } & x^{2}=11.29, \text { d.f. }=1 & .47 \\ & p<.01 \\ & x^{2}=6.43, \text { d.f. }=1 & \end{array}$

to $77.4 \%$ at the father's remarriage and $66.7 \%$ at the remarriage of the exwife.

The Chi-square test for independence was applied to the $2 \times 2$ tables created by examining frequency of visit by geographic distance for each marital status and the Phi coefficient computed to indicate the strength of the relationship between frequency and distance. The association is nonexistent for separation, .03 (NS); weak for divorce, $.26(\mathrm{p} .<.05)$; and moderate for the remarriage of 
either spouse. The association at the father's remarriage is .47 (p. $<.001)$ and at the exwife's remarriage is .47 (p. $<.001)$. It can be concluded that distance is a significant intervening variable determining visiting frequency; however, marital status still affects visiting frequency when distance is controlled.

Catholics visited more frequently than Protestants at all marital statuses. Differences were small at the separation and divorce statuses but at the father's remarriage, $76.9 \%$ (10) of the Catholics visited more frequently compared to $51.6 \%$ (16) of the Protestants. After the remarriage of the exwife, $80.0 \%$ (4) of the Catholics visited more frequently compared to $40.9 \%$ (9) of the Protestants.

After the remarriage of the exwife, Classes I and II respondents visited more frequently than Classes III and IV respondents. Although the total number of respondents in these four categories was only 28 , the trend is unmistakable. In Classes I and II, $75.0 \%$ (3) and $70.0 \%$ (7) of the fathers visited more frequently compared with $30.0 \%$ (3) of Class III and 25.05 (1) of Class IV.

While continuity of support did not have much influence on visiting frequency at the separation and divorce status, after the remarriage of the father, $62.9 \%$ (22) of those who never stopped payment visited more frequently compared with $50.0 \%$ (7) of the fathers who had stopped payment. After the remarriage of the exwife the contrast is even greater. Of those who had never stopped payment, $52.4 \%$ (11) visited more frequently compared with $37.5 \%$ (3) of the fathers who had stopped payment.

The relationship between the father and the exwife also showed no effect on visiting frequency at the time of the divorce. However, in terms of supporting the father's relationship with his children, $84.2 \%$ (32) of fathers whose exwife supported the relationship visited more frequently compared with $65.7 \%$ (23) of those whose exwife opposed the relationship. While this finding did not attain statistical significance, it approached significance at the .07 level. Unfortunately, it is not possible to compare this relationship at the two remarried statuses since the questionnaire design did not yield the necessary data.

\section{DISCUSSION}

It seems obvious that the restructuring of the paternal role following separation and divorce is affected not only by remarriage and important intervening variables, but by the very nature of the parental 
roles involved. Whatever responsibility the father feels for responding to requests for additional support following separation and divorce, it increases noticeably if he remarries but reduces drastically if his exwife remarries. The increase in support following the father's remarriage is supported by Cassetty (1978) who found that Caucasian men who are already supporting their children increase their level of support after their remarriage. It would appear that the current wife intervenes to encourage the father to find some alternative to role reduction as a solution to the extra demands on his resources incurred through remarriage. This interpretation is supported by other data in the study which showed that $80 \%$ of second wives accepted their husbands allocation of money to their first children at the time of the marriage. This increased to $81.5 \%$ by the time of the interview. In a related finding, $74.6 \%$ of the men reported their second wives were interested in and involved in the lives of their stepchildren.

The marked drop in voluntary support after the remarriage of the exwife indicates a significant reduction in role related to the introduction of a stepfather into the role constellation. However, this effect does not appear to apply to court-ordered support payments. Only two men reported requesting a change in support payments due to the remarriage of the exwife. However, there were a number who did not give reasons for requesting changes in support orders. Some explanations for the drop in voluntary support are found in the number of men $(35.5 \%)$ who indicated that the stepfathers should be the ones most responsible or totally responsible for the support of stepchildren. Another $17.8 \%$ felt that the responsibility should be equally shared.

The effect of marital status on personal contact was somewhat different depending upon the varible being examined. Although the changes were not great, phone calls decreased after the remarriage of the father but increased after the remarriage of the exwife. Visiting frequency declined following the remarriage of both parties. The demands on resources would differ considerably between these two types of personal contacts. Visiting is more time consuming and expensive than phone calls, therefore, the latter are less likely to be affected by new role obligation. The decrease in phone calls following the father's remarriage is puzzling, but may be too small to be significant. The increase in phone calls following the remarriage of the exwife is however, compatible with the decrease in visiting frequency that occurs at the same marital status. It seems 
reasonable that less frequent visits would result in increased phone contacts.

The decline in visiting frequency is supported by the Goode, Weiss and Hetherington et al., studies reported earlier. However, none of these studies associate changes in visiting frequency with remarriage. Alexander's finding that remarriage did not result in a decrease in visiting frequency is not in agreement with the findings of this study. Visiting frequency was not the major issue in her study however, and there is not sufficient detail presented in the article to permit a comparison of the conflicting data. Also, the large number of fathers in this study who continued to visit their children is at odds with Anspach's study in which a little over half of the fathers were reported by their exwives as not visiting at all.

It seems obvious that the decline in visiting frequency does not denote a decline in paternal interest or involvement. The findings on phone calls, plus the increase in visiting length accompanying the decline in frequency, indicate a reordering of roles. It is possible that, as summer visits are utilized as the primary visiting mode, father and child may spend more time together after the father's remarriage than they did during the separation or divorced periods when they saw each other more frequently but for shorter periods of time.

The four variables that did not attain statistical significance also indicate possible effects on visiting frequency. These were religion, attitude of the exwife, support and social class. There is no ready explanation of why Catholics visited more frequently than Protestants at all marital statuses.

Unfortunately, the construction of the questionnaire did not permit comparison of visiting frequency and the attitudes of the exwife toward the father-child relationship at the remarriage of either exspouse. Whether the pattern of opposition which appeared to reduce visiting frequency found at divorce would continue after remarriage is not known. It seems likely that it would and that the attitude of the exwife has an important effect on visiting frequency. Newsome's study found that sentiments of the exwife to be a significant, if not always understood, intervening variable in permitting access to the children.

Visiting frequency also appeared related to continuity of support in that those who stopped or missed payments did not visit as frequently as those who had never missed a payment. This only occurred for the two remarried statuses and not for the separated and 
divorced statuses. Only $26.7 \%$ (23) of the men reported ever stopping or missing payments. This is a far different experience than that reported by Goode (1965) who found only $35 \%$ of exwives who reported regular payments and $40 \%$ who reported that payments were never made. More recent data indicate that only $26.0 \%$ of all separated, divorced and remarried women report receiving support payments (U.S. Bureau of the Census, 1979). These data are based on the exwife's responses and are, therefore, not comparable to those of this study. However, it seems reasonable to assume that a man's claim to visitation rights weakens when he is delinquent in his payments, and the Goode and Newsome studies bear this out.

Social class also gave indications of having an impact on visiting frequency since, after the remarriage of the exwife, the higher classes visited more frequently than the lower classes. As noted earlier, Weiss proposed that income level will influence visiting frequency when geographic distance is involved.

While Goode does not deal directly with visiting frequency, he does discuss the exwife's preferences for increased or decreased visiting based on some of the variables that have been considered here. He notes that $14.0 \%$ of the exwives wished that the father would not visit at all and another $20.0 \%$ wished that he would visit less often. In Goode's study the desire for less frequent visiting was associated with the remarriage of the exwife, continuity of support and her desire to punish the exhusband.

It can be concluded, then, that marital status does have an effect on visiting frequency. In addition, it seems highly probably that visiting frequency is also affected by geographic distance with the upper classes being less influenced than the lower classes. Negative attitudes of the exwife toward the father-child relationship will decrease visiting frequency at the time of the divorce. Continuity of support payments will also have negative effects on visiting frequency regardless of marital status. The remarriage of the exwife has a greater negative relationship to visiting frequency than the remarriage of the father. No particular conclusions can be drawn from the effect of religion on visiting frequency. It remains unexplained.

There are two potentially significant variables which have not been included in this study. One is the possible effect of the ages of the children on visiting frequency. As noted earlier, children at different ages present both different needs and different problems in relation to visiting. The second is the effect of visiting on the children's behavior. Goode noted that negative evaluations of the 
mother relative to the children's pre and post visiting behavior resulted in a desire for decreased father-child contacts. How much the decline in visiting frequency associated with remarriage might be a function of either age changes in the children or the mother's evaluation of the children's pre and post visiting behavior needs further investigation.

\section{SUMMARY AND CONCLUSIONS}

This study has examined the effect of remarriage on voluntary support and personal contacts between father and child following divorce. The evidence suggests that remarriage does have an effect on voluntary support and that this effect is diametrically different depending upon which parental role is modified by remarriage. None of the ten other variables tested intervened in a way that changed the direction of these results. The analysis also reveals the complexity of the role configurations that are created through remarriage, a fact that has been largely ignored in examining post-divorce behavior. As is often characteristic of exploratory research, more questions are raised than answered. Several issues emerge to be considered in future research.

The first is that measures of visiting frequency offer a limited explanation of the nature of the post-divorce relationship between father and child. The increases in the duration of visits and the continued use of phone contacts suggests that the paternal bond, although affected by the impact of other role commitments, is not readily abandoned by all fathers. What stretches these bonds to the breaking point need further explanation.

The second important issue relates to the stepmother role. The findings that voluntary support increases but visiting frequency decreases after the remarriage of the father raises questions. Why, and under what conditions, do second wives support the allocation of their husband's financial resources to the children even though these must be subtracted from the resources available to her and, in some cases, her children. What part does the second wife play in the decision to change the visiting pattern to longer, but less frequent visits? Are these decisions based on maternal interest, convenience, the presence of an additional adult for supervision, or other considerations?

Although the impact of additional role obligations is the theme of 
this analysis, the role of the stepfather, added when the exwife remarries, has not been included. The part that this position plays in reducing voluntary support and changing the visiting pattern is needed before a complete understanding of post-divorce behavior can be achieved.

\section{REFERENCES}

Alexander, S. J. Influential factors on divorced parents in determining visiting arrangements. Journal of Divorce, 1980, 3, 223-239.

Anspach, D. Kinship and divorce. Journal of Marriage and the Family, 1976, 38, 323-330.

Bohannan, P. Divorce chains, households of remarriage, and multiple divorcers. P. Bohannan (Ed.), Divorce and Afier. Garden City, New York: Anchor Books Edition (1971).

Cassetty, J. Child Support and Public Policy. Lexington: D.C. Heath and Co., 1978.

Cline, D. and Westerman, J. The impact of divorce on the family. Child Psychiatry and Human Development, 1971, 2, 78-83.

Goldsmith, J. Relationships between former spouses: descriptive feelings. Unpublished paper presented at the National Council of Family Relations, Boston, 1979.

Goode, W. J. Women in Divorce. New York: Free Press, 1965.

Grief, J. B. Child absence: father's perceptions of their relationship to their children subsequent to divorce. Dissertation Abstracts International, 1977, 37, (2-A), 820.

Hetherington, E. M., Cox, M. and Cox, R. Divoreed fathers. The Family Coordinator, $1976,25,416-428$.

Hollingshead, A. B. and Redlich, F. C. Social Class and Mental Illness, New York: Wiley, 1958.

Kessler, R. and Cleary, P. Social class and psychological stress. American Sociological Review, 1980, 45, 463-478.

Newsome, O. D. Postdivorce interaction: an explanation using exchange theory. Dissertation Abstracts International 1977, 38, (12-A), 8001.

Newsome, O. D. After the divorce: problems of husbands and exwives. Unpublished paper presented at the 74th Annual Meeting of the American Sociological Association, Boston, 1979.

Weiss, R. S. Marital Separation. New York: Basic Books, Inc., 1975.

U.S. Bureau of the Census. Divorce, child custody and child support. Current Population Reports, series P-20: 84. Washington, D.C.: Government Printing Office, 1979. 